\title{
THE INFLUENCE OF THE STRUCTURAL CHARACTERISTICS OF COTTON AND POLYESTER KNITTED FABRICS ON THE THERMO-PHYSIOLOGICAL COMFORT
}

Sonja Jordeva ${ }^{1 *}$, Sonja Ćortoševa ${ }^{2}$, Kiro Mojsov ${ }^{1}$, Silvana Žežova ${ }^{1}$, Sanja Risteski ${ }^{1}$, Vangja D. Kuzmanoska ${ }^{1}$

1University "Goce Delčev", Faculty of Technology, Štip, Macedonia

2University "Ss. Cyril and Methodius", Faculty of Technology and Metallurgy, Skopje, Macedonia

Assuring the thermo-physiological comfort of the human body is one of the most important functions of clothing, especially of underwear, sportswear and casual wear. Knitted fabrics should not only posses elasticity and provide freedom of movement, but they should also have good handle, a high level of clothing comfort and easily transmitted vapour from the body. In this paper, the influence of cotton and the polyester knitted structure on thermal comfort properties was investigated. The results obtained indicate that the structure of knitted fabrics shows a more significant influence on thermo-physiological comfort than the raw material content.
(PROFESSIONAL PAPER) UDC 677.075:687.1:677.014 ester knitted fabrics, thermo-physiological comfort, air and water vapour permeability, thermal conductivity

\section{Introduction}

Knitting technology is faced with rapid changes in terms of the requirements of fashion and user performances. Knitted fabric should not only be resilient and allow freedom of movement, but have a nice touch, and the clothes should easily transport moisture from the body. Consumer demands in terms of the quality of clothes are changed in accordance with the development of textile technology and the rise of living standards. Providing thermal stability of the human body is one of the important functions of garments, especially of daily, underwear and sportswear [1]. The term comfort is defined as "the absence of displeasure or discomfort" or "a neutral state compared to the more active state of pleasure" [2]. According to Slater, comfort is a pleasant state of thermo-physiological harmony between a person and the environment [3]. The comfort of clothing is a complex phenomenon but can be generally divided into four types: the first type is called thermo-physiological comfort and has a direct impact on thermoregulation of the person who wears clothes. In this comfort thermal insulation, breathing of clothes and transmission of moisture through clothing are included $[1,4]$.

Thermal conductivity is an intensive property of the material that indicates its ability to conduct heat [5]. Thermal resistance is the measure of thermal insulation of the material. It is defined as the quantity of heat transmitted through the unit thickness in a direction normal to the surface of the unit area, due to the unit temperature gradient under steady state conditions, and when the heat transfer is dependent only on temperature. As we can see from the definition, it is necessary to know the rate of the heat transfer through the material in order to measure its thermal resistance [6].

The second kind of feeling on the skin (touch comfort) is manifested through the mechanical contact of tex tiles with the skin. In this direct contact pleasant feeling of softness and tenderness or uncomfortable itching, scratching or sticking to the skin may occur. The third type is the ergonomic comfort of clothing. It refers to the adjustment of clothing to the body and freedom of movement. This kind of comfort is of special importance for sportswear. Last but not least is a psychological comfort. It is dependent on fashion trends, personal beliefs, ideology. This kind of comfort can not be measured, everyone feels comfortable in different clothes with a different color or model [1,4]. Thermo-physiological comfort, which is the subject of this paper covers thermoregulation and moisture management. It is known that the type of fiber, the characteristics of the yarn, the structure of knitted fabrics and finishing are the main factors affecting thermo-physiological comfort [1]. In this paper, the impact of structural characteristics of cotton and polyester knitted fabrics on thermo-physiological features of comfort was investigated.

\section{Experimental part}

Materials and methods

Four cotton and three polyester knitted fabrics were manufactured and investigated. Cotton knitted fabrics are made from a $100 \%$ cotton yarn (yarn count $\mathrm{T}_{\mathrm{t}}=20$ tex) as single jersey $1: 1$, double jersey, $1: 1$, interlock and interlock 14:1. Polyester knitted fabrics are made of a $100 \%$ polyester filament with fineness of $\mathrm{Tt}=33,3$ tex.

The investigation of the air permeability was performed according to the standard EN ISO 9237:1999. An FF-12 Metrimpex instrument was used with difference in the contact pressure of $20 \mathrm{~Pa}$ and the area of the sample $10 \mathrm{~cm}^{2}$. Air permeability was assessed by the amount of the air flow which passes through the sample,

\footnotetext{
* Author address: Sonja Jordeva, University "Goce Delčev", Faculty of Technology,

Štip, Miro Baraga bb., Probištip, Macedonia

E-mail: sonja.jordeva@ugd.edu.mk

The manuscript received: April, 08, 2017.

Paper accepted: May, 23, 2017.
} 
$Q\left(\mathrm{dm}^{3} / \mathrm{h}\right)$. The results are the average of 10 measurements. During the test the air flow was measured, and then the coefficient of air permeability $B \Delta p$ was determined according to the relation 3 [7].

$B_{\Delta p}=\frac{Q}{360 S}\left(\frac{m}{s}\right)$.

\section{Where is S- sample area $\left(\mathrm{cm}^{2}\right)$}

The investigation of water vapor permeability was performed on a sample with $15 \times 15 \mathrm{~cm}$ dimensions. All the measurements were done under standard climatic conditions with the apparatus consisting of a thermostat and a glass with $62 \mathrm{~cm}^{2}$ surface (internal diameter $89 \mathrm{~mm}$ ). Water was put in the glass until the level of water rose up to $35 \mathrm{~mm}$ below the upper glass edge. The glass was covered with the sample and put under the influence of water vapor with the temperature of $500{ }^{\circ} \mathrm{C}$ for four hours. After 4 hours, the loss of water was determined and the mass increment of the sample, $\mathrm{Pv}$, and the procedure was repeated under the same conditions for four more hours. According to the given results, the water vapor permeability was calculated with the following relation 2 [8]:

$P V P=\frac{m_{v}-P_{v}}{A t} 100\left(\mathrm{mg} / \mathrm{cm}^{2} \mathrm{~h}\right)$.

In order to measure the thermal conductivity coefficient of the knitted fabrics, the method known as Dr. Bok was used. The instrument worked according to standards ASTM C518, ISO 8301. The thermal resistance was defined with the equation [7].

$R_{c t}=\frac{h}{\lambda}\left(\frac{m^{2} K}{W}\right)$

where: Rct-thermal resistance, $\left(\mathrm{m}^{2} \mathrm{~K} / \mathrm{W}\right), \mathrm{h}-$ fabric thickness $(\mathrm{m}), \lambda-$ thermal conductivity $(\mathrm{W} / \mathrm{mK})$.

\section{Results and discussion}

Structural characteristics

In Table 1 and Figure 1 the structural characteristics of used knitted fabrics are given. Course density, Dh $\left(\mathrm{cm}^{-1}\right)$ and wale density, Dv $\left(\mathrm{cm}^{-1}\right)$, fabric thickness, $\mathrm{h}(\mathrm{mm})$ mass per unit area $\mathrm{m}\left(\mathrm{g} / \mathrm{m}^{2}\right)$ and loop length, I $(\mathrm{mm})$ were determined according to standard methods. Density $D\left(\mathrm{~cm}^{-2}\right)$ is the result of multiplication of Dh and Dv. Tightness factor TF(tex $\left.{ }^{1 / 2} / \mathrm{cm}\right)[9,10]$ and porosity $P$ (\%) [3] were calculated according to equations 4 and 5 :

$T F=\frac{\sqrt{T_{t}}}{l}\left(\frac{\sqrt{t e x}}{\mathrm{~cm}}\right)$

$P=\left(1-\frac{m}{\rho h}\right) 100(\%)$

where: Tt-yarn count (tex), I-loop length ( $\mathrm{mm}), \rho$-density $\left(\mathrm{kg} / \mathrm{m}^{3}\right), \mathrm{m}$-mass per unit area $\left(\mathrm{g} / \mathrm{m}^{2}\right)$, h-fabric thickness $(\mathrm{mm})$.
Table 1. The structural characteristics of used knitted fabrics

\begin{tabular}{|c|c|c|c|c|c|c|c|c|c|c|c|}
\hline z & 总 & $\begin{array}{c}\text { Raw } \\
\text { material } \\
\text { content } \\
(\%)\end{array}$ & & $\begin{array}{c}\mathrm{Dh} \\
\left(\mathrm{cm}^{-1}\right)\end{array}$ & $\begin{array}{c}\mathrm{Dv} \\
\left(\mathrm{cm}^{-1}\right)\end{array}$ & $\begin{array}{c}D \\
(\mathbf{c m} \\
-1)\end{array}$ & $\underset{(\mathrm{mm})}{\mathrm{I}}$ & $\underset{\left(g / m^{2}\right)}{m}$ & $\underset{(\mathrm{mm})}{\mathrm{h}}$ & $\begin{array}{r}\text { L } \\
\stackrel{\dot{5}}{:}\end{array}$ & $\begin{array}{c}P \\
(\%)\end{array}$ \\
\hline 1 & $\begin{array}{c}\text { Single } \\
\text { jersey } \\
\text { (DL) }\end{array}$ & $\begin{array}{c}100 \\
\text { cotton }\end{array}$ & $\begin{array}{c}\bar{x} \\
\operatorname{Cv}(\%)\end{array}$ & $\begin{array}{c}15.0 \\
(0.45)\end{array}$ & $\begin{array}{c}19.0 \\
(1.36)\end{array}$ & 285 & $\begin{array}{c}2.65 \\
(2.17)\end{array}$ & $\begin{array}{c}150 \\
(2.08)\end{array}$ & $\begin{array}{l}0.463 \\
(2.29)\end{array}$ & 16.8 & 78.7 \\
\hline 2 & $\begin{array}{c}\text { Double } \\
\text { jersey } \\
1: 1 \\
\text { (DD) }\end{array}$ & $\begin{array}{c}100 \\
\text { cotton }\end{array}$ & $\begin{array}{c}\bar{x} \\
\operatorname{Cv}(\%)\end{array}$ & $\begin{array}{c}12.0 \\
(1.87)\end{array}$ & $\begin{array}{c}13,5 \\
(1.87)\end{array}$ & 324 & $\begin{array}{c}3.00 \\
(2.40)\end{array}$ & $\begin{array}{c}180 \\
(5.34)\end{array}$ & $\begin{array}{l}0.701 \\
(3.52)\end{array}$ & 14.9 & 83.0 \\
\hline 3 & $\begin{array}{c}\text { Interloc } \\
\mathrm{k}\end{array}$ & $\begin{array}{c}100 \\
\text { cotton }\end{array}$ & $\begin{array}{c}\bar{x} \\
\operatorname{Cv}(\%)\end{array}$ & $\begin{array}{l}12.2 \\
(1.5)\end{array}$ & $\begin{array}{c}13.5 \\
(0.89)\end{array}$ & 329 & $\begin{array}{c}2.90 \\
(6.50)\end{array}$ & $\begin{array}{c}205 \\
(1.19)\end{array}$ & $\begin{array}{l}0.745 \\
(3.18)\end{array}$ & 15.4 & 81.8 \\
\hline 4 & $\begin{array}{c}\text { Interloc } \\
\mathrm{k}\end{array}$ & $\begin{array}{c}100 \\
\text { cotton }\end{array}$ & $\begin{array}{c}\bar{x} \\
\operatorname{Cv}(\%)\end{array}$ & $\begin{array}{c}14.0 \\
(0.84)\end{array}$ & $\begin{array}{c}14.0 \\
(1.14)\end{array}$ & 392 & $\begin{array}{c}2.85 \\
(6.60)\end{array}$ & $\begin{array}{c}217 \\
(1.47)\end{array}$ & $\begin{array}{l}0.874 \\
(2.96)\end{array}$ & 15.7 & 83.5 \\
\hline 5 & $\begin{array}{c}\text { Single } \\
\text { jersey } \\
\text { (DL) }\end{array}$ & $\begin{array}{l}100 \\
\text { PES }\end{array}$ & $\begin{array}{c}\bar{x} \\
\operatorname{Cv}(\%)\end{array}$ & $\begin{array}{c}9.5 \\
(0.84)\end{array}$ & $\begin{array}{c}11.0 \\
(0.55)\end{array}$ & 104 & $\begin{array}{c}4.4 \\
(2.20)\end{array}$ & $\begin{array}{c}151 \\
(4.99)\end{array}$ & $\begin{array}{l}0.869 \\
(2.99)\end{array}$ & 12.7 & 87.0 \\
\hline 6 & $\begin{array}{c}\text { Double } \\
\text { jersey } \\
2: 2 \\
\text { (DD) }\end{array}$ & $\begin{array}{l}100 \\
\text { PES }\end{array}$ & $\begin{array}{c}\overline{\mathbf{x}} \\
\operatorname{Cv}(\%)\end{array}$ & $\begin{array}{c}8.5 \\
(0.84)\end{array}$ & $\begin{array}{c}10 \\
(1.14)\end{array}$ & 170 & $\begin{array}{c}5.8 \\
(8.40)\end{array}$ & $\begin{array}{c}330 \\
(4.77)\end{array}$ & $\begin{array}{l}1.679 \\
(3.43)\end{array}$ & 10.0 & 85.9 \\
\hline 7 & $\begin{array}{c}\text { Interloc } \\
\mathrm{k}\end{array}$ & $\begin{array}{l}100 \\
\text { PES }\end{array}$ & $\mathrm{Cv}(\%)$ & $\begin{array}{c}9 \\
(0.84)\end{array}$ & $\begin{array}{c}9 \\
(0.89)\end{array}$ & 162 & $\begin{array}{c}5.4 \\
(4.20)\end{array}$ & $\begin{array}{c}289 \\
(4.51)\end{array}$ & $\begin{array}{l}1.434 \\
(1.58)\end{array}$ & 10.7 & 85.3 \\
\hline
\end{tabular}

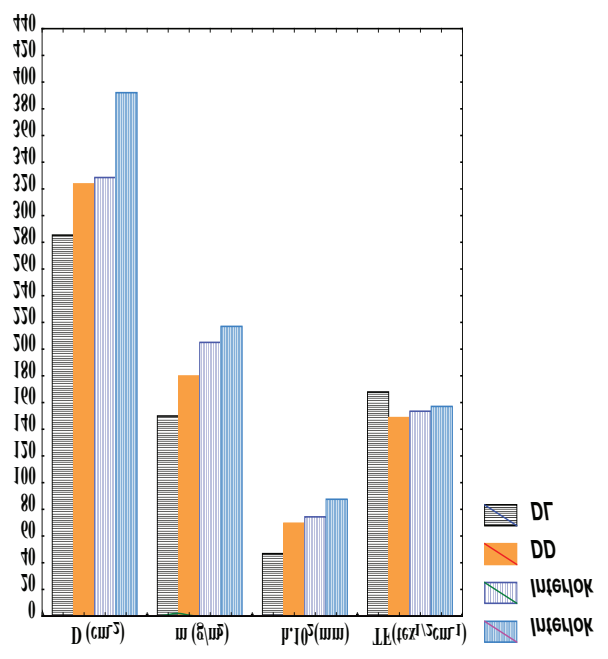

(a)

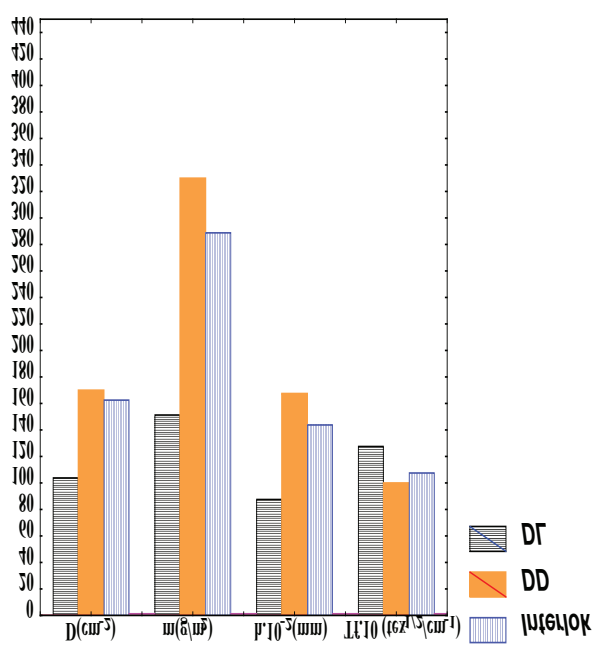

Figure 1. Density (D), m-mass per unit area, h-fabric thickness and tightness factor TF of a) cotton and b) polyester knitted fabrics 
Air and water vapour permeability

In Table 2, air permeability values of cotton and polyester knitted fabrics are given.

Table 2. Air permeability of knitted fabrics

\begin{tabular}{llccc}
\hline No. & Structure & $\begin{array}{c}\text { Air } \\
\text { permeability } \\
\mathbf{Q}\left(\mathbf{d m}^{3} / \mathbf{h}\right)\end{array}$ & $\begin{array}{c}\text { Coefficient of } \\
\text { variation } \\
\mathbf{C v}(\%)\end{array}$ & $\begin{array}{c}\text { Coefficient of air } \\
\text { permeability } \\
\mathbf{B}_{\Delta \mathbf{p}}(\mathbf{m} / \mathbf{s})\end{array}$ \\
\hline & Single jersey & 545 & 0.96 & \\
2 & Single jersey $1: 1$ & 1100 & 19.2 & 0.151 \\
3 & Interlock & 972 & 24.2 & 0.306 \\
4 & Interlok & 820 & 2.4 & 0.270 \\
& & PES knitted fabrics & $(100 \%)$ & 0.228 \\
5 & Single jersey & 1930 & 2.5 & \\
6 & Double jersey $2: 2$ & 1141 & 4.5 & 0.536 \\
7 & Interlock & 675 & 3.5 & 0.289 \\
\hline
\end{tabular}

Air permeability $Q$ of cotton knitted fabrics with different structure ranges from $545-1100\left(\mathrm{dm}^{3} / \mathrm{h}\right)$ what is the difference of $101,8 \%$ and expressed as a coefficient of air permeability $B \Delta p=0.151-0.306(\mathrm{~m} / \mathrm{s})$. Air permeability $\mathrm{Q}$ of knitted polyester ranges in values of $675-1930\left(\mathrm{dm}^{3} / \mathrm{h}\right)$, representing a difference of $185.9 \%$, respectively, expressed as a coefficient of air permeability $B \Delta p=0.187-0.536(\mathrm{~m} / \mathrm{s})$. The great difference in the values of the air permeability is due to the differences in thickness and porosity of knitted fabrics with the different structure. The results showed a statistically significant correlation between porosity and air permeability of knitted fabrics, (fig. 2). Porosity depends on structural parameters of knitted fabrics, the loop length - I and cover factor-TF. With the increase of the loop length, porosity increased and a knitted fabric became more extensible.
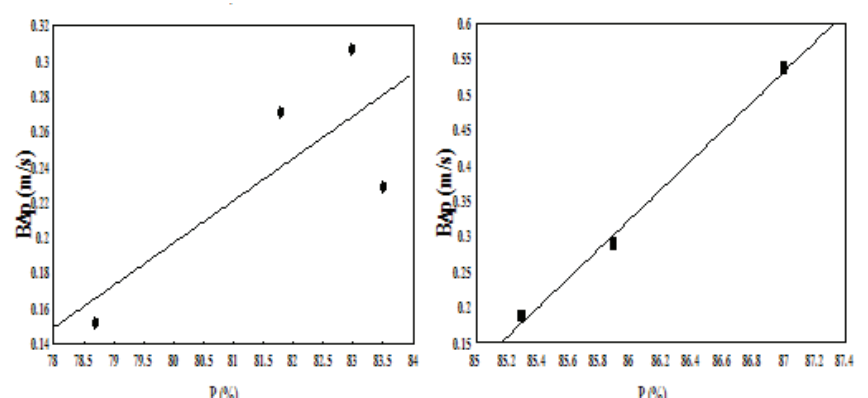

Figure 2. Correlation between the coefficient of air permeability $\mathrm{B} \Delta \mathrm{p}(\mathrm{m} / \mathrm{s})$ and porosity $\mathrm{P}(\%)$ of a) cotton and b) polyester knitted fabrics

In Table 3, the results of water vapor permeability of knitted fabrics are given.

It can be observed that water vapor permeability-PVP (for 4 to 8 hours) for the cotton knitted fabrics depends on the porosity $P$ (Fig.3). By increasing the porosity of knitted fabrics the water vapor permeability increases. By increasing the thickness and mass per unit area of knitted fabrics, water vapor permeability decreases (Fig. 4).
Table 3. Water vapor permeability of knitted fabrics

\begin{tabular}{|c|c|c|c|c|c|c|c|}
\hline \multirow[b]{2}{*}{$\dot{z}$} & \multicolumn{3}{|c|}{ Cotton knitted fabrics } & \multirow[b]{2}{*}{ ì } & \multicolumn{3}{|c|}{ PES knitted fabrics } \\
\hline & Structure & $\begin{array}{c}\text { PVP, 4h } \\
\left(\mathrm{mg} / \mathrm{cm}^{2} \mathrm{~h}\right)\end{array}$ & $\begin{array}{l}\text { PVP, } 8 \mathrm{~h} \\
\left(\mathrm{mg} / \mathrm{cm}^{2} \mathrm{~h}\right)\end{array}$ & & Structure & $\begin{array}{c}\text { PVP, 4h } \\
\left(\mathrm{mg} / \mathrm{cm}^{2} \mathrm{~h}\right)\end{array}$ & $\begin{array}{l}\text { PVP, 8h } \\
\left(\mathrm{mg} / \mathrm{cm}^{2} \mathrm{~h}\right)\end{array}$ \\
\hline 1 & $\begin{array}{l}\text { Single jersey } \\
\text { Double jersey }\end{array}$ & 62.17 & 54.19 & 5 & $\begin{array}{l}\text { Single jersey } \\
\text { Double jersey }\end{array}$ & 75.1 & 62.4 \\
\hline 2 & $1: 1$ & 75.70 & 68.10 & 6 & $2: 2$ & 52.3 & 50.1 \\
\hline 3 & Interlock & 72.85 & 61.14 & 7 & Interlock & 60.0 & 60.0 \\
\hline 4 & Interlock & 70.15 & 60.44 & & & & \\
\hline
\end{tabular}
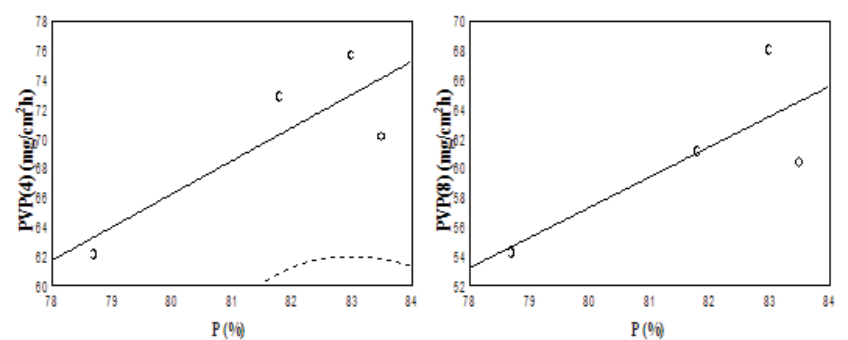

Figure 3. Correlation between water vapor permeability PVP $\left(\mathrm{mg} / \mathrm{cm}^{2} \mathrm{~h}\right)$ and porosity $\mathrm{P}(\%)$ of cotton knitted fabrics for a) 4 hours and b) 8 hours
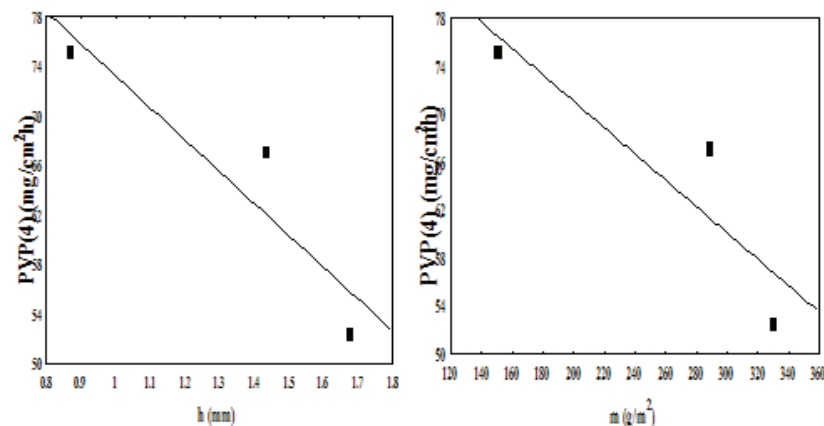

Figure 4. Correlation between water vapor permeability PVP $\left(\mathrm{mg} / \mathrm{cm}^{2} \mathrm{~h}\right)$ and a) thickness $(\mathrm{h})$ and b) mass per unit area $(\mathrm{m})$ of polyester knitted fabrics

Thermal conductivity and thermal resistance

In Table 4, the results of thermal conductivity $\lambda(\mathrm{W} /$ $\mathrm{mK})$ and thermal resistance $\mathrm{R}_{\mathrm{ct}}\left(\mathrm{m}^{2} \mathrm{~K} / \mathrm{W}\right)$ of knitted fabrics are given.

Table 4. Thermal conductivity $(\lambda)$ and thermal resistance ( $\left.R_{c t}\right)$ of knitted fabrics

\begin{tabular}{llcc}
\hline No & \multicolumn{1}{c}{ Structure } & $\begin{array}{c}\boldsymbol{\lambda} \\
\mathbf{( W / m K )}\end{array}$ & $\begin{array}{c}\mathbf{R}_{\mathrm{ct}} \\
\left(\mathbf{m}^{2} \mathbf{K} / \mathbf{W}\right)\end{array}$ \\
\hline \multicolumn{4}{c}{ Cotton knitted fabrics } \\
1 & Single jersey & 0.0647 & 0.0210 \\
2 & Double jersey 1:1 & 0.1002 & 0.0105 \\
3 & Interlock & 0.0911 & 0.0136 \\
4 & Interlock & 0.1045 & 0.0127 \\
& $\quad$ Polyester knitted fabrics \\
5 & Single jersey & 0.0480 & 0.0310 \\
6 & Double jersey 2:2 & 0.1796 & 0.0129 \\
7 & Interlock & 0.0855 & 0.0267 \\
\hline
\end{tabular}

Thermal conductivity $-\lambda$ of the cotton knitted fabrics is in the range of values $0.0647-0.1045(\mathrm{~W} / \mathrm{mK})$ representing a difference of $61.5 \%$. The results show that the thermal conductivity decreases towards Interlock>Double 
jersey $>$ Single jersey. The polyester knitted fabrics have the highest thermal conductivity Double jersey 2:2, followed by Interlock, and Single jersey knitted fabric has the smallest. This distribution of values for thermal conductivity in cotton and polyester knitted fabrics is the result of a heavier knitted fabric, more mass per unit area have higher thermal conductivity. With the increase of the mass per unit area of the cotton and polyester knitted fabric, the thermal conductivity- $\lambda$ increases due to the larger amount of fibers per unit area, (Fig. 5).
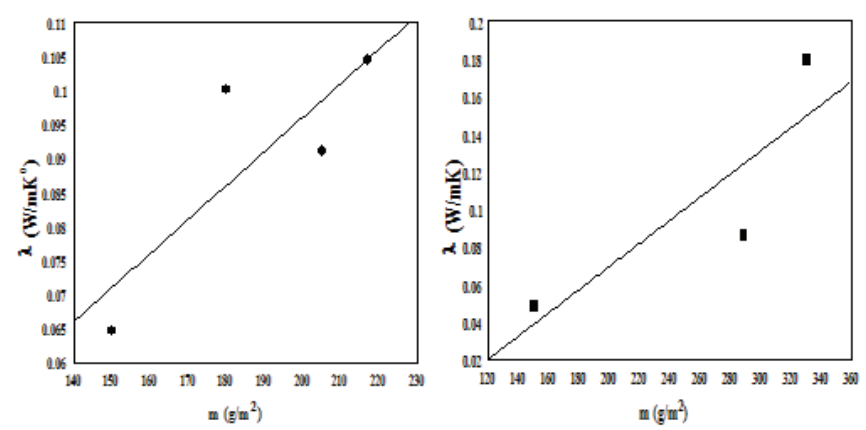

Figure 5. Correlation of thermal conductivity $(\lambda)$ and mass per unit area $(\mathrm{m})$ of a) cotton and b) polyester knitted fabrics

A significant linear correlation can be observed between the thermal conductivity- $\lambda$ and tightness factorTF for both raw compositions, for cotton and for polyester knitted fabrics. Single jersey knitted fabrics with a greater tightness factor have a greater value to thermal resistance-Rct, while the double jersey knitted fabrics and interlock with a lower tightness factor have lower thermal resistance, (Fig. 6).
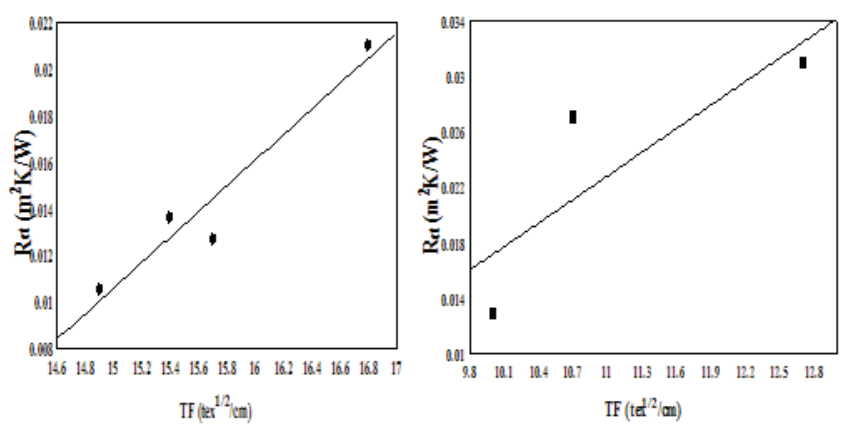

Figure 6. Correlation of thermal resistance $\left(R_{c t}\right)$ and tightness factor (TF) of a) cotton and b) polyester knitted fabrics

\section{Conclusion}

The investigation of the impact of structural characteristics of cotton and polyester knitted fabrics with a different structure on the properties of thermo-physiological comfort leads to the following conclusions: air permeability and water vapor permeability mostly depend on the porosity of knitted fabrics, more than on the of raw material content. Water vapor permeability of the polyester knitted fabrics is correlated with thickness and mass per unit area. By increasing the thickness or mass per unit area of knitted fabrics, water vapor permeability is reduced. A statistically significant correlation between water vapor permeability and porosity of cotton knitted fabrics was noticed. Knitted fabrics with a higher tightness factor have higher thermal resistance. The relation between the structural characteristics of knitted fabrics and properties of thermo-physiological comfort is not simple because the change of one structural characteristic leads to the change of others, and that in turn affects the comfort.

\section{References}

[1] S. Roshan, Textiles in Sport, Woodhead Publishing, Cambridge, 2005, p.177-201.

[2] N. Oglakcioglu, A. Marmarali, Thermal comfort properties of some knitted structures, Fibres\&Textiles in Eastern Europe, 15(5-6) (2007) 94-96.

[3] N. Odzil, A. Marmarali, S. D. Kretzschmar, Effect of yarn properties on thermal comfort of knitted fabrics, International Journal of Thermal Sciences, 46(12) (2007) 1318-1322.

[4] G. Jiangman, The effects of household fabric softeners on the thermal comfort and flammability of cotton and polyester fabrics. Thesis, Faculty of the Virginia Polytechnic Institute and State University, 2003.

[5] M.Matusiak, Investigation of the thermal insulation properties of multilayer textiles, Fibres\&Textiles in Eastern Europe, 14(5) (2006) 98-102.

[6] B.P. Saville, Physical Testing of Textiles, Woodhead Publishing, Cambridge, 1999, p. 209-234.

[7] Д. Стояанова Германова-Крстева, Раководство за Лабораторни Упражнения по Текстилни Испитвания и Анализ, Технически Университет, София, 2007, р. 2-75.

[8] R. Čunko, Ispitivanje Tekstila, Sveučilišna Naklada, Zagreb, 1988, p. 221-223.

[9] S. M. Kortoševa, Matematičko-statistički model na reološkite svojstva na desno-desni pletenini. Doktorska disertacija, Tekstilen institut, Tehnološko-Metalurški Fakultet, Skopje, 2000.

[10] Z. Vrljičak, Osnovni parametri pletiva, Tekstil, 31(2) (1982) 95-106. 


\section{Izvod \\ UTICAJ STRUKTURNIH KARAKTERISTIKA PAMUČNIH I POLIESTERSKIH PLETENINA NA TERMOFIZOLOŠKI KOMFOR}

Sonja Jordeva ${ }^{1}$, Sonja Ćortoševa ${ }^{2}$, Kiro Mojsov ${ }^{1}$, Silvana Žežova ${ }^{1}$, Sanja Risteski ${ }^{1}$, Vangja D. Kuzmanoska ${ }^{1}$

1Univerzitet “Goce Delčev", Štip, Tehnološko-tehnički fakultet, Probištip, Makedonija

2Univerzitet “Sv. Kiril i Metodij”, Tehnološko-metalurški fakultet, Skoplje, Makedonija

Obezbeđivanje termičke stabilnosti ljudskog tela jedna je od najvažnijih funkcija odeće, naročito za svakodnevnu i sportsku odeću kao i za rublje. Pletiva namenjena za odeću ne treba da budu samo elastična i da omogućavaju slobodu kretanja, već da imaju i prijatni opip, da budu komforne i da lako propuštaju vodenu paru. U radu je istraživan uticaj strukturnih karakteristika pamučnih i poliesterskih pletenina na termofiziološki komfor. Dobijeni rezultati pokazuju da, u poređenju sa sirovinskim sastavom, strukturne karakteristike ispitivanih pletenina imaju esterske pletenine, termofiziološki komfor, propustljivost vazduha i vodene pare, za sačajniji uticaj na termofiziološki komfor. toplotna provodljivost 